\title{
Assessment of genotypes of silkworm (Bombyx mori L.) for organic sericulture
}

\author{
Litvin V., Babayeva G., Dmitriyeva 0. \\ National Scientific Center "Institute of Experimental and Clinical Veterinary Medicine"
}

The purpose. Rate genotypes from the gene pool collection of silkworm for use in organic silk production in Ukraine. Methods. Laboratory and analytical, hybridization and selection, thermostatic, statistical data using bio-economic indicators genotypes silkworm. Results. Selected genotypes from the gene pool collection of silkworm are resistant to adverse environmental factors. They are therefore suitable for organic production of larvae, pupae, and cocoons of silkworm eggs. At the same culture conditions moth should be close to nature, including feeding caterpillars organic mulberry leaves. The genotypes have a higher viability of caterpillars, cocoon weight, the proportion of high-quality cocoons and cocoon crop compared to the control breed Merefa 6. Conclusions. Selected from a gene pool collection silkworm genotypes may be used in organic production system sericulture Ukraine.

Key words: organic sericulture, cocoons, mulberry-fed caterpillars, Bombyx mori L., breed, clone, genotype.

In developed countries, the priority issue is the preservation and improvement of human health and animals. So every year the share of production and consumption of organic products [1]. Nowadays such products in Ukraine is mainly imported. To import in our country need to develop the appropriate field, including sericulture.

In the scientific literature are the main motives transition livestock producers on organic technologies [2]. However, Ukraine is far behind, especially in the production of animal organic products. The reasons for this are analyzed in many scientific articles, mainly economic direction [3-5].

Silk - a branch of agriculture breeding silkworm cocoons for, giving silk. In Ukraine, mostly cultivated silkworm. This type of moth only fully domesticated species of butterflies, which in the wild is not there. Food for silkworm caterpillars mulberry leaves are. In our previous article [6] presents bred resistant to adverse environmental conditions mulberry varieties that can be grown in the organic production. This is the first stage in the creation of organic silk in general.

Sericulture Industry in the scientific literature has not yet investigated the creation of a system of organic production. At the same time in the trading network can buy expensive imported products from natural silk (textile, clothing) quality are not labeled as organic.

Therefore, due to the great demand among customers for products made of natural silk and silk other products, of import substitution, had started work on breeding breeding resistant species and hybrids of silkworm, first Shovkostantsiyi, and the Institute of Agrarian Sciences of silk. However, the ability to set up silkworm genotypes grown under conditions of organic production has not been investigated.

Purpose - to evaluate genotypes from the gene pool collection silkworm for organic sericulture Ukraine.

Research Methodology. Silkworm genotypes were established in the Department of Sericulture and Entomology Technology National Science Center "Institute of Experimental and Clinical Veterinary Medicine" in the 2000-2016 biennium.

Experiments conducted in compliance with the organic production of livestock genotypes adapted to feeding silkworm, the main are: complete elimination of chemical protection at all stages of insect development. Curling tracks performed only on kokonnykah of natural dried plants. Vyhodivli room 
lighting was natural sunlight. Floor cleaning, maintaining moisture indoors, wetting the leaves from wilting was tested for harmful contaminants in natural artesian water.

The base starting material to create a species and hybrids was silkworm gene pool, which includes 110 species of different geographical origins represented lines 118 and 125 subline that are donors of useful properties [7]. Ukraine Cabinet has identified research facility silkworm gene pool considered a national treasure of the country.

In the process of data feeding silkworm genotypes were determined by the following indicators: the viability of caterpillars (\%); high-quality cocoon weight (g); share high-quality cocoons (\%); crop of cocoons $1 \mathrm{~g}$ husenyts- "Murashi" (kg). Control zoned served breed Merefa 6.

The study was conducted according to guidelines developed for the conditions of Ukraine [8]. Feeding caterpillars, cocoons perm, butterflies mating was performed according to methods developed in sericulture. [9] Statistical analysis of the results was carried out by generally accepted biometric methods [10].

Results. On the basis of laboratory studies identified a number of biological and economic features of silkworm genotypes to determine their overall resilience to stressful environmental factors.

Evaluation results silkworm genotypes for complex agronomic traits in terms of Kharkiv region found 6 best species (Table.).

The research demonstrates the viability of genotypes that all 6 species significantly $(p<0,01-0,001)$ exceeds breed Merefa 6 . However, the largest average significantly $(p<0.001)$ should breed Ukrainian 23 $(88,11 \pm 1,70) \%$. Excess of control is 12.23 abs. \% $(P<0.001)$.

All species tested well with high-quality cocoon weight significantly $(p<0,01-0,001)$ higher in comparison with the control species Merefa $6(1,63 \pm 0,05) \mathrm{g}(\mathrm{p}<0.001)$. At the same time we have established breed silkworm Ukrainian 23 with the highest average weight cocoon $(2,15 \pm 0,05) \mathrm{g}$ ( $\mathrm{p}$ $<0.001$ ).

Analysis of the data table. shows. that the value of high-quality contents silkworm cocoons genotypes highly significantly $(p<0.001)$ higher than the corresponding figure control species. The greatest value of high-quality content reaches a cocoon breeds Merefa $8(92,00 \pm 1,12) \%$.

Analysis of the data table. shows. that the value of high-quality contents silkworm cocoons genotypes highly significantly $(p<0.001)$ higher than the corresponding figure control species. The greatest value of high-quality content reaches a cocoon breeds Merefa $8(92,00 \pm 1,12) \%$.

Harvest cocoons of $1 \mathrm{~g}$ husenyts- "Murashi" moth genotype was significantly $(p<0,01-0,001)$ higher compared with the control species $(2,53 \pm 0,09)$, except for Ukrainian rock 18 , the indicator which does not differ from controls $(2,66 \pm 0,09) \mathrm{kg}(p>0.05)$.

\section{Basic biological and economic indicators silkworm genotypes compared with the control species} Merefa $6(M \pm m)$

\begin{tabular}{|c|c|c|c|c|}
\hline Genotypes & Viability caterpillar, & $\%$ Cocoon weight, $\mathrm{g}$ & High-quality content cocoons., \% & Cocoons yield, kg \\
\hline Merefa 6 (control) & $75,88 \pm 1,66$ & \begin{tabular}{|l|l}
$1,63 \pm 0,05$ \\
\end{tabular} & $81,04 \pm 0,93$ & \begin{tabular}{|l|}
$2,53 \pm 0,09$ \\
\end{tabular} \\
\hline Ukrainian 15 & $\underset{* * *}{86,831,75}$ & $1,87 \pm 0,04$ & $87,58 \pm 1,12$ & $3,26 \pm 0,12$ \\
\hline Ukrainian 18 & $83,54 \pm 1,76$ & $1,87 \pm 0,05$ & $87,55_{* \star *} \pm 0,98$ & $2,66 \pm 0,09$ \\
\hline Ukrainian 22 & $82,07 \pm 1,64$ & $2,03 \pm 0,04$ & $87 \underset{* * \star}{38 \pm 1,10}$ & $\underset{* \star}{2,93 \pm 0,11}$ \\
\hline Ukrainian 23 & $88, \underset{* \star \star}{11 \pm 1,70}$ & $2, \underset{\star \star \star *}{2} \pm 0,05$ & $91,39_{* \star \star} \pm 1,13$ & $3, \underset{* \star *}{20}, 11$ \\
\hline Merefa 7 & $84, \underset{* * \star}{97 \pm 1,74}$ & $2, \underset{* * *}{10 \pm 0,04}$ & $90,22 \pm 1,08$ & $\underset{* * *}{3,58 \pm 0,12}$ \\
\hline Merefa 8 & $86,91 \pm 1,84$ & $1,79 \pm 0,05$ & $92,00 \pm 1,12$ & $2,93 \pm 0,10$ \\
\hline
\end{tabular}

Thus, experimental studies have shown that selected genotypes from the collection of silkworm gene pool can be effectively grown under conditions close to the natural conditions of existence of their 
ancestors. Because the technology of cultivation of the silkworm different from the industrial cultivation of silkworms. Feeding proposed species of silkworm mulberry leaves organic, grown on certified soil without the use of chemical fertilizers and remedies, will help obtain a competitive product innovation in the form of larvae, pupae, cocoons and articles. So evaluated genotypes silkworm suggests that feeding is quite possible for the "Rules of production of organic products (raw materials) animal."

The implementation in practice of the results of this work will contribute to job creation, integration of Ukraine into the global trading system, providing information producers on the benefits of organic silk production direction.

\section{Conclusions}

Reviewed genotypes from the collection of silkworm gene pool for use in organic silk. They can be cultivated under the rules of organic production (raw materials) of animal origin. Genotype significantly increased viability include caterpillars, cocoon weight, cocoon contents varietal and harvest the cocoons compared to controls breed Merefa 6. Species, Ukrainian 15,18, 22, 23, Merefa 7, 8, proposed for implementation in small and large agricultural enterprises to obtain organic production of (caterpillars, cocoons, pupae and Gren). The prospect of further investigations in this direction is the development of new silkworm genotypes with improved biological and economic indicators.

\section{References}

1. Legeza D. G. Proces rozvitku virobnictva organichnoï produkciï v Ukraïni/D. G. Legeza//Visnik Nacional'nogo universitetu «L'vivs'ka politehnika», serija «Problemi ekonomiki ta upravlinnja»._2010._ № 683. - S. 99-104

2. Vdovichenko Ju.V., Omel'chenko L.O. Efektivnist' rozvedennja hudobi pivdennoï m'jasnoï porodi v umovah organichnogo virobnictva/Ju.V.Vdovichenko, L.O., Omel'chenko//Naukovo-teoretichnij fahovij zhurnal Naukovij visnik «Askanija-Nova». - 2012. - Vip. 5. - Ch. II - S. 3 - 11.

3. Koval'chuk S. Ja. Virobnictvo organichnoï produkciï - agrarna specializacija Ukraïni na mizhnarodnomu rinku/S.Ja. Koval'chuk, L.V. Muljar//Zb. Nauk. prac' VNAU. - Serija Ekonomichni nauki. - Vinnicja: VNAU, 2013. - № 3. - S. $104-110$.

4. Pis'mens'ka O.A. Rozvitok organichnogo sil's'kogo gospodarstva v Єvropi/ O.A. Pis'mens'ka //Ekonomika APK, - 2012. - № 2, - S.141-144.

5. Nazarkevich O.B. Virobnictvo organichnoï produkciï malimi sil'gosppidpriemstvami v konteksti vimog koncepciï stalogo rozvitku/O.B. Nazarkevich//Visnik dnipropetrovs'kogo derzhavnogo agrarnoekonomichnogo universitetu. - 2015. - № 1 (35). - S. $25-28$.

6. Sorti plodovoï shovkovici dlja organichnogo sadivnictva/G.I. Baba€va, V.M. Litvin, V.I. Vojtenko, T.S. Hmel'ova//Visnik agrarnoï nauki. - 2016. - N 12. - S. 16-19.

7. Selekcija tutovogo shelkoprjada v Ukraine : dostizhenija, problemy, perspektivy / V. A. Golovko, M. E. Braslavskij, A. Z. Zlotin, V. V. Kazmiruk. — Har'kov: Original, 2001. - 271 s.

8. Praktichnijposibnik po shovkivnictvu: dovidnik/l.O.Kirichenko[tain.].-K.:Urozhaj, 1991._144s.

9. Shovkivnictvo: Kniga dlja studentiv biologichnih i sil's'kogospo- dars'kih special'nostej vuziv, vikladachiv biologiï shkil ta agronomiv-shov-kivnikiv/V.O. Golovko, O.Z. Zlotin, M.Ju. Braslavs'kij ta in. .$\mathrm{H} .:$ RVP «Original», 1998. $-416 \mathrm{~s}$.

10. Lakin G.F. Biometrija: ucheb. posobie/G.F. Lakin. - M.: Vyssh. shk., 1990. - 352 s 